\title{
The COVID-19 Impact in Hospital Healthcare Workers: Development of an Occupational Health Risk Management Program
}

\author{
Luís Mendonça-Galaio ${ }^{\mathrm{a}-\mathrm{c}}$ Ema Sacadura-Leite ${ }^{\mathrm{a}-\mathrm{d}}$ João Raposo ${ }^{\mathrm{a}}$ \\ Diana França $^{a}$ Ana Correia ${ }^{a}$ Rodrigo Lobo ${ }^{a}$ Jorge Soares ${ }^{a}$ Clara Almeida $^{a}$

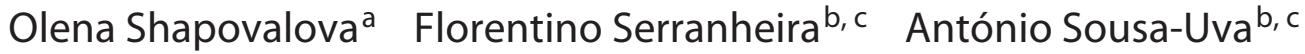 \\ ${ }^{a}$ Department of Occupational Health, Centro Hospitalar Universitário Lisboa Norte, Lisbon, Portugal; ${ }^{b}$ Public Health \\ Research Centre (PHRC/CISP), Comprehensive Health Research Centre (CHRC), Lisbon, Portugal; ' Occupational \\ and Environmental Health Department of NOVA National School of Public Health, Lisbon, Portugal; ${ }^{d}$ Institute for \\ Preventive Medicine and Public Health of University of Lisbon School of Medicine, Lisbon, Portugal
}

\section{Keywords}

COVID-19·SARS-CoV-2 · Healthcare workers · Occupational health $\cdot$ Health management software

\begin{abstract}
As with the SARS-CoV-1 outbreak in 2003-2004 and the MERS outbreak in 2012, there were early reports of frequent transmission to healthcare workers (HCW) in the SARS-CoV-2 pandemic. Our hospital center identified its first COVID-19 confirmed case on March 9, 2020, in a 6-day hospitalized patient. The first confirmed COVID-19 case in a HCW happened 3 days later, in a nurse with a probable epidemiological link related to the first confirmed patient. Our study's first objective is to describe and characterize the impact of the first 3 months of the SARS-CoV-2 pandemic on the Centro Hospitalar Universitário Lisboa Norte (CHULN). Our second objective is to report the performance of the CHULN Occupational Health Department (OHD) and the impact of the pandemic on CHULN HCW and its adaptation across national, regional, and institutional epidemiological evolution. Over the first 3 months, 2,152 HCW were screened (which represent $29.8 \%$ of the total HCW population), grouped in 100 separate identifiable clusters, each one ranging from 2 to 98
\end{abstract}

karger@karger.com www.karger.com/pjp

Karger $\stackrel{\text { ' }}{5}$

GOPEN ACCESS
(C) 2021 The Author(s)

Published by S. Karger AG, Basel on behalf of NOVA National School of Public Health

This is an Open Access article licensed under the Creative Commons Attribution-NonCommercial-4.0 International License (CC BY-NC) (http://www.karger.com/Services/OpenAccessLicense), applicable to the online version of the article only. Usage and distribution for commercial purposes requires written permission.
$\mathrm{HCW}$. The most prevalent profession screened were nurses ( $n=800 ; 37.2 \%)$ followed by doctors ( $n=634 ; 29.5 \%$ ). The main source of potential infection and cluster generating screening procedures was co-worker related $(n=1,216$; $56.5 \%)$. A patient source or a combined patient co-worker source was only accountable for $559(26 \%)$ and $43(2 \%)$ of cases, respectively. Our preliminary results demonstrate a lower infection rate among HCW than the ones commonly found in the literature. The main source of infection seemed to be co-worker related rather than patient related. New preventive strategies would have to be implemented in order to control SARS-CoV-2 spread.

\section{(C) 2021 The Author(s). Published by S. Karger AG, Base on behalf of NOVA National School of Public Health}

COVID-19 impacto em profissionais de saúde de um hospital: desenvolvimento de um programa de gestão do risco em saúde ocupacional

Palavras Chave

COVID-19 · SARS-CoV-2 · Profissionais de saúde · Saúde Ocupacional · Software de gestão em saúde 


\section{Resumo}

À semelhança dos surtos de SARS-CoV-1, em 2003-2004 e de MERS, em 2012, a pandemia de SARS-CoV-2 apresentou, desde o seu início, relatos de transmissão frequente da doença a profissionais de saúde (PS). O nosso Centro Hospitalar identificou o seu primeiro caso confirmado de COVID-19 a 9 de março de 2020, num paciente hospitalizado há 6 dias. O primeiro caso de COVID-19 confirmado num PS ocorreu 3 dias depois, numa enfermeira com vínculo epidemiológico provavelmente relacionado com o primeiro paciente confirmado. $\mathrm{O}$ primeiro objetivo do nosso estudo é descrever e caracterizar o impacto dos primeiros 3 meses da pandemia de SARS-CoV-2 no Centro Hospitalar Universitário Lisboa Norte (CHULN). O nosso segundo objetivo é relatar o desempenho do Serviço de Saúde Ocupacional (SSO) do CHULN em relação ao impacto da pandemia no CHULN HCW e sua adaptação ao longo da evolução epidemiológica nacional, regional e institucional. Durante os primeiros três meses, foram rastreados 2.152 PS (o que representa $29,8 \%$ da população total de PS), agrupados em cem clusters distintos, cada um dos quais variando entre 2 e 98 PS. A profissão rastreada mais prevalente foi a de enfermeiro $(n=800 ; 37,2 \%)$ seguido do médico ( $n=634 ; 29,5 \%$ ). A principal fonte de infecção identificada (simultaneamente, geradora de procedimentos de triagem de clusters) esteve relacionada com outros colegas de trabalho $(n=1.216 ; 56,5 \%)$. Uma fonte originada num paciente ou uma fonte combinada de paciente e colega de trabalho foram responsáveeis por apenas $559(26 \%)$ e $43(2 \%)$ dos casos, respectivamente. Os nossos resultados preliminares demonstram uma taxa de infecção mais baixa entre os profissionais de saúde do que as comumente encontradas na literatura. A principal fonte de infecção parecia estar relacionada com colegas de trabalho e não com o paciente. Novas estratégias preventivas deverão que ser implementadas para controlar a propagação do SARS-CoV-2 em contexto profissional.

(c) 2021 The Author(s) Published by S. Karger AG, Basel on behalf of NOVA National School of Public Health

\section{Introduction}

On December 8, 2019, a pneumonia outbreak of unknown etiology was first identified in Hubei City, Wuhan province, China. Chinese CDC reports the occurrence to the World Health Organization (WHO) China Country Office on December 31, 2019 [1,2].

WHO names the disease COVID-19, an acronym for coronavirus disease 2019, on February 11, 2020 [3]. The agent causing the infection was a novel coronavirus des- ignated SARS-CoV-2 by the Coronavirus Study Group $[4,5]$.

The disease spreads fast across the country and, soon after, across the world leading the WHO to declare the COVID-19 outbreak as a global health emergency, on January 30, 2020 and as a global pandemic on March 11, 2020. The last time had been in 2009 for the H1N1 influenza pandemic $[6,7]$. Infections from SARS-CoV-2 are now widespread [8].

SARS-CoV-2 is the seventh coronavirus known to infect humans, the third that can cause severe disease, but the first and only human coronavirus with pandemic potential [9-11]. There is an equal likelihood of contagion for any person or worker. When we consider healthcare workers, namely, the ones dedicated to the diagnosis, treatment and care of infected patients, or laboratory professionals that directly manipulate biological products containing the virus, one could say that they have a specific risk that bears a higher probability of infection, which necessarily determines the need for specialized protection measures [12]. Similar to the SARS-CoV-1 outbreak in 2003-2004 and the MERS outbreak in 2012, there were early reports of frequent transmission to healthcare workers (HCW), including several with fatal outcome [13]. They are expected to be one of the groups most exposed to SARS-CoV-2 infection, and surveillance of the proportion of seropositive HCW is an important indicator of the spread of the virus [14].

Our hospital center identified its first COVID-19 confirmed case on March 9, 2020, in a 6-day hospitalized patient. The first confirmed COVID-19 in a HCW happened 3 days later, in a nurse with a probable epidemiological link related to the first confirmed patient. The Occupational Health Department (OHD) started its follow-up program of risk contacts and suspected cases evaluation that ended up with the development of a new dashboard, which allows daily reports to each involved department or ward supervisor, hospital directors and Portuguese Health Authority.

The health information system includes the standardization of criteria and the dissemination of data processing methodologies in order to allow the comparison of health indicators that will provide information on best practices $[15,16]$.

Our goal is to ensure the transparency of the entire COVID-19 prevention process in the OHD, fundamental for HCW management decisions [17].

\section{Objectives}

Our study's first goal is to describe and characterize the impact of the first 3 months of the SARS-CoV-2 pandem- 
Table 1. COVID-19 screening results during the first trimester of the pandemic at CHULN

\begin{tabular}{|c|c|c|c|c|}
\hline & 1st month, $n(\%)$ & 2nd month, $n(\%)$ & 3rd month, $n(\%)$ & Total, $n(\%)$ \\
\hline Total exposure screening & $1,177(47.4)$ & $465(18.7)$ & $510(20.6)$ & $2,152(100)$ \\
\hline \multicolumn{5}{|l|}{ Sex } \\
\hline Women & $921(78.2)$ & $374(80.4)$ & $395(77.5)$ & $1,690(78.5)$ \\
\hline Men & $256(21.8)$ & $91(19.6)$ & $115(22.5)$ & $462(21.5)$ \\
\hline \multicolumn{5}{|l|}{ Occupation } \\
\hline Doctor & $397(33.7)$ & $105(22.6)$ & $132(25.9)$ & $634(29.5)$ \\
\hline Nurse & $427(36.3)$ & $182(39.1)$ & $191(37.5)$ & $800(37.2)$ \\
\hline Nurse aid & $303(25.7)$ & $118(25.4)$ & $120(23.5)$ & $541(25.1)$ \\
\hline Technician & $102(8.7)$ & $37(8.0)$ & $32(6.3)$ & $171(7.9)$ \\
\hline Clerk & $83(7.1)$ & $20(4.3)$ & $25(4.9)$ & $128(5.9)$ \\
\hline Cleaning staff & $17(1.4)$ & $1(0.2)$ & $4(0.8)$ & $22(1.0)$ \\
\hline Other & $5(0.4)$ & $2(0.4)$ & $6(1.2)$ & $13(0.6)$ \\
\hline \multicolumn{5}{|l|}{ Age, years } \\
\hline Mean & 40.9 & 40.2 & 40.5 & 40.6 \\
\hline Standard deviation & 12.2 & 12.2 & 12.2 & 12.2 \\
\hline Maximum; minimum & $20 ; 70$ & $20 ; 69$ & $22 ; 68$ & $20 ; 70$ \\
\hline \multicolumn{5}{|l|}{ Source } \\
\hline Unknown & $152(12.9)$ & $70(15.1)$ & $63(12.4)$ & $285(13.2)$ \\
\hline Patient & $287(24.4)$ & $105(22.6)$ & $167(32.7)$ & $559(26.0)$ \\
\hline Co-worker & $684(58.1)$ & $276(59.4)$ & $256(50.2)$ & $1,216(56.5)$ \\
\hline Patient + co-worker & $43(3.7)$ & $0(0.0)$ & $0(0.0)$ & $43(2.0)$ \\
\hline Cohabitant & $5(0.4)$ & $4(0.9)$ & $8(1.6)$ & $17(0.8)$ \\
\hline Non-cohabitant family & $1(0.1)$ & $9(1.9)$ & $8(1.6)$ & $18(0.8)$ \\
\hline Community & $5(0.4)$ & $1(0.2)$ & $8(1.6)$ & $14(0.7)$ \\
\hline \multicolumn{5}{|l|}{ Cluster } \\
\hline Total & 43 & 27 & 30 & 100 \\
\hline Maximum; minimum per cluster & $2 ; 98$ & $2 ; 47$ & $2 ; 85$ & $2 ; 98$ \\
\hline \multicolumn{5}{|l|}{ Exposure risk } \\
\hline Symptomatic & $353(30.0)$ & $138(29.7)$ & $133(26.1)$ & $624(29.0)$ \\
\hline High risk & $365(31.0)$ & $126(27.1)$ & $199(39.0)$ & $690(32.1)$ \\
\hline Low risk & $418(35.5)$ & $181(38.9)$ & $151(29.6)$ & $750(34.9)$ \\
\hline Asymptomatic without contact & $40(3.4)$ & $17(3.7)$ & $12(2.4)$ & $69(3.2)$ \\
\hline Did not answer & $1(0.1)$ & $3(0.6)$ & $15(2.9)$ & $19(0.9)$ \\
\hline \multicolumn{5}{|l|}{ OHD action } \\
\hline Active symptom surveillance & $461(39.2)$ & $175(37.6)$ & $135(26.5)$ & $771(35.8)$ \\
\hline Negative PCR screening & $603(51.2)$ & $261(56.1)$ & $332(65.1)$ & $1,196(55.6)$ \\
\hline Positive PCR screening & $60(5.1)$ & $12(2.6)$ & $15(2.9)$ & $87(4.0)$ \\
\hline PCR screening declined & $12(1.0)$ & - & $1(0.2)$ & $13(0.6)$ \\
\hline Asymptomatic without contact & $33(2.8)$ & $15(3.2)$ & $12(2.4)$ & $60(2.8)$ \\
\hline Did not answer & $1(0.1)$ & $2(0.4)$ & $15(2.9)$ & $18(0.8)$ \\
\hline Portuguese Health Authority & $3(0.3)$ & - & - & $3(0.1)$ \\
\hline Corrupt data & $4(0.3)$ & & & $4(0.2)$ \\
\hline
\end{tabular}

ic on the Centro Hospitalar Universitário Lisboa Norte (CHULN) quantified in the total number of cases identified, number of suspected cases officially reported to the $\mathrm{OHD}$ and their clinical and epidemiological characteristics.

Our second objective is to report the performance of the CHULN OHD and the impact of the pandemic on the CHULN HCW and its adaptation across national, regional, and institutional epidemiological evolution.

\section{Materials and Methods}

In order to answer our first objective, we developed a crosssectional study, involving all 7,220 workers of the CHULN, between March 11 and June 12. Our inclusion criteria were: (1) being a CHULN HCW; (2) with symptomatology suspicion of COVID-19; (3) having a high-risk or low-risk contact with a known COVID-19 patient or colleague. No exclusion criteria were listed. Participation was voluntary. To meet our second objective, we carried out a narrative analysis of the OHD performance, during the evolution of the pandemic, and its adaptation effort by developing 
a software application (dashboard) to help gather, process, study and provide all data to all relevant partners.

In accordance with the Portuguese Health Authority, ECDC and the WHO, we use the following definitions: (i) symptomatology suspicious of COVID-19, we [18] included any HCW with at least one of the following symptoms: cough, fever, shortness of breath, sudden onset of anosmia, ageusia or dysgeusia (additional less specific symptoms included headache, chills, muscle pain, fatigue, vomiting and/or diarrhea); (ii) high-risk exposure (close contact), we considered any HCW providing care to a COVID-19 confirmed case or handling specimens from a COVID-19 case, without recommended Personal Protective Equipment (or with a possible breach of PPE) or having had face-to-face contact with any COVID-19 case within $2 \mathrm{~m}$ for $>15 \mathrm{~min}$ [18-20]; (iii) low-risk exposure was defined as any healthcare worker providing care to a COVID-19 case, or laboratory workers handling specimens from a COVID-19 case, wearing the recommended PPE or having had face-to-face contact or been in a closed environment with any COVID-19 case within $2 \mathrm{~m}$ for $<15 \mathrm{~min}$ [18-20].

All selected cases whether, self-reported or reported by the wards, underwent a detailed medical interview in order to discriminate any associated symptoms and to scrutinize the nature of the contact with the aim of classifying the associated infection risk. All symptomatic HCW underwent an immediate nasopharyngeal swab to determine the presence of SARS-CoV-2 through a Reverse Transcription Polymerase Chain Reaction (RT-PCR) test. All asymptomatic high-risk contacts performed a nasopharyngeal swab to determine the presence of SARS-CoV-2 through a RTPCR 4-5 days after the suspicious contact. All laboratory-positive cases begun sick leave and were reported to the national COVID-19 patient registry. All laboratory-negative persons as well as all asymptomatic low-risk contacts begun an active daily symptom surveillance until the 14th day after the suspected contact and were reported to the OHD in case of any symptomatology. Any set of HCW being surveyed from one common COVID-19 patient were grouped in a cluster. Data were gathered from the CHULN OHD digital archive.

\section{Results}

Over the first 3 months, 2,152 HCW were screened (which represent $29.8 \%$ of the total HCW population), grouped in 100 separate identifiable clusters, each one ranging from 2 to $98 \mathrm{HCW}$.

Our screened population (Table 1) had a mean age of 40.6 years and was composed mainly of females $(n=$ $1,690 ; 78.5 \%)$. The most prevalent occupations screened were nurses $(n=800 ; 37.2 \%)$ followed by doctors $(n=$ $634 ; 29.5 \%)$ and nurses aid $(n=541 ; 25.1 \%)$. Technicians and clerks had minor impact $(n=171 ; 7.9 \%$ and $n=128$; $5.9 \%$, respectively).

One relevant fact uncovered was that the main source of potential infection and cluster generating screening procedures was co-worker related $(n=1,216 ; 56.5 \%)$. A patient source or a combined patient co-worker source was only accountable for 559 (26\%) and 43 (2\%) of cases, respectively. In 285 of the situations screened (13.2\%), no source was identified. Familial and community sources had residual influence on the cases screened. The relative proportions of all variables identified remained constant throughout the 3 months of screening.

Risk classification was evenly distributed with an overall prevalence of $29.0,32.1$ and $34.9 \%$ for symptomatic HCW, high-risk and low-risk exposure, respectively.

During this first trimester, 1,283 RT-PCR were prescribed, which diagnosed 87 cases of COVID-19 among HCW (6.8\%) which represent $4.0 \%$ of screened HCW and $1.2 \%$ of the total HCW. By the end of June, Portugal counted 42,171 confirmed cases (about $0.41 \%$ of the Portuguese population) $[21,22]$. During the course of our study, Portugal had a 14-day incidence rate average of 48.94 per $10^{5}$ (reaching a 103.4 peek by week 15) [8].

\section{Discussion}

The $1.2 \%$ infection rate among HCW and the $6.8 \%$ of positive results obtained from all swabs prescribed in our study during the first 3 months of the pandemic were considerably lower than the ones found in the literature.

$\mathrm{Wu}$ and McGoogan [2] found an incidence of COVID-19 among HCW of $3.8 \%(n=1,716 \mathrm{HCW}$ confirmed cases out of 44,672 total confirmed cases). Within the same time span, but in a Tertiary Hospital in Wuhan, China, Lai et al. [23] found an infection rate of $1.1 \%$ (110 of 9,684) among hospital HCW.

In Lombardy, Italy, one study found $8.8 \%(n=$ $139 / 1,573$ ) of positive results [24]. Although we could not find a concrete regional 14-day incidence rate per $10^{5}$ data, by the time of the study, Lombardy was the most affected Italian region [25]. In Verona, a total of 11,890 specimens collected in a combined mass screening and contact tracing strategy targeting close contacts, 238 positive swabs were obtained, yielding a cumulative incidence of $4.0 \%$ [25]. The higher results could be explained because Italy reported a much higher incidence of disease in the community $(128,948$ confirmed cases which account for about $0.2 \%$ of the total population) [8].

In a Madrilene hospital $11.6 \%(n=791)$ of all hospital HCW tested positive for SARS-CoV-2 (38\%) [26]. This result is higher than ours because a high 14-day incidence rate was observed [8].

In Newcastle, researchers found $14 \%(n=240)$ positive tests for HCW [27]. At the Sheffield Teaching Hospitals, $282 \mathrm{HCW}$ were positive for SARS-CoV-2, which repre- 
sents a $1.65 \%$ cumulative incidence out of the $17,000 \mathrm{em}$ ployed staff [28].

In the Netherlands, a study involving 1,653 symptomatic HCW, $6 \%(n=86)$ had a positive SARS-CoV-2 RTPCR test (1\%) [29].

In our OHD CHULN, we chose to classify and stratify the risk of exposure [18-20] and to identify the most probable source of infection rather than to infer the risk and source of infection by relying on the characteristics of specific HCW activities such as working in the first line versus non-first line of care, or working in a COVID versus non-COVID dedicated ward or ICU, or yet dealing directly or not with patients as some of the cite authors do [2, 23-29]. By doing so, we found that $56.5 \%$ of potential HCW infection and cluster generating screening procedures were co-worker related. Regardless of the specific activity, a patient source or a combined patient/coworker source was only accountable for 26 and $2 \%$ of cases, respectively and in $13.2 \%$ of the situations screened, no source was identified. As familial and community sources had residual influence on the cases screened, our data point to the fact that in the first 3 months of pandemic in our hospital centre, HCW mainly infecting each other during meals, break periods or in locker rooms.

Since early January, CHULN OHD became involved in the adaptation effort to the new reality through: (1) articulation with other hospital sectors in the design of a contingency plan; (2) development of training and information actions for HCW; (3) design and implementation of a surveillance plan of $\mathrm{HCW}$ with exposure to COVID-19 patients and early diagnosis of positive cases; (4) identification of HCW considered to have greater sensitivity to the development of disease with greater severity, that allow ending with a dashboard that help OHD managing HCW health and prevention strategies.

\section{Conclusions}

Our preliminary results demonstrate a lower infection rate among HCW than the ones commonly found in the literature. The main source of infection seemed to be coworker related rather than patient related. New preventive strategies would have to be implemented in other to control SARS-CoV-2 spread.

The generalized use of the software application developed in our hospital would be beneficial not only to optimize human resources, but also to standardize data upload to regional and national authorities and to provide common ground to scientific pandemic impact comparison.

\section{Acknowledgements}

The authors wish to thank nurses Ana Furtado, Isabel Pereira, Regina Rocha and Graça Temudo and our clerk Marina Xavier. The authors also would like to acknowledge the effort carried out by Dr. Francisco Caridade and all his H2ST crew that relentlessly worked in the development of our healthcare management software.

\section{Statement of Ethics}

This research complies with the guidelines for human studies and was conducted ethically in accordance with the World Medical Association Declaration of Helsinki receiving the scientific ethical approval of the Lisbon's Medical Academical Center and the Centro Hospitalar Lisboa Norte Ethics Committee. Gathered data were based on SCHULN OHD clinical records and were previously anonymized, thus informed consent was not required.

\section{Conflict of Interest Statement}

The authors have no conflicts of interest to declare.

\section{Funding Sources}

FCT - Fundação para a Ciência e Tecnologia (Proj. No. 053 Intervenção da Saúde Ocupacional junto dos profissionais de saúde com exposição a $S A R S-C o V-2$ [Covid-19] na recuperação da pandemia).

\section{Author Contributions}

L.M.-G. is accountable for all aspects of the work, ensuring that questions related to the accuracy or integrity of any part of the work are appropriately investigated and resolved. L.M.-G. and E.S.-L. were responsible for data acquisition, design, analysis, and interpretation of data. J.R., D.F., A.C., R.L., J.S., C.A., and O.S. were responsible for data acquisition. E.S.-L., F.S., and A.S.-U. were responsible for revising it critically for important intellectual content and final approval of the version to be published.

References

Port J Public Health

1 Thompson KA, Pappachan JV, Bennett AM, Mittal H, Macken S, Dove BK, et al.; EASE Study Consortium. Influenza aerosols in UK hospitals during the H1N1 (2009) pandemic-the risk of aerosol generation during medical procedures. PLoS One. 2013;8(2):e56278.

$2 \mathrm{Wu} \mathrm{Z}, \mathrm{McGoogan}$ JM. Characteristics of and important lessons from the Coronavirus Disease 2019 (COVID-19) outbreak in China: Summary of a Report of 72314 Cases From the Chinese Center for Disease Control and Prevention. JAMA. 2020 Apr;323(13):1239-42. 
3 Ghebreyesus TA. WHO Director-General's remarks at the media briefing on $2019-\mathrm{nCoV}$ on 11 February 2020 [Internet]Geneva: World Health Organization; 2020. [cited 2020 Apr 1], Available from https://www.who.int/ $\mathrm{dg} /$ speeches/detail/who-director-general-sremarks-at-the-media-briefing-on2019-ncov-on-11-february-2020.

4 Gorbalenya AE, Baker SC, Baric RS, de Groot RJ, Drosten C, Gulyaeva AA, et al. Severe acute respiratory syndrome-related coronavirus: the species and its viruses: a statement of the Coronavirus Study Group. bioRxiv [Internet]. 2020;2020.02.07.937862. Available from: https://www.biorxiv.org/content/10.1101/20 20.02.07.937862v1.

5 Gorbalenya AE, Baker SC, Baric RS, de Groot RJ, Drosten C, Gulyaeva AA, et al.; Coronaviridae Study Group of the International Committee on Taxonomy of Viruses. The species Severe acute respiratory syndromerelated coronavirus: classifying 2019-nCoV and naming it SARS-CoV-2. Nat Microbiol. 2020 Apr;5(4):536-44.

6 Jin Y, Yang H, Ji W, Wu W, Chen S, Zhang W, et al. Virology, epidemiology, pathogenesis, and control of COVID-19. Viruses. 2020 Mar;12(4):372.

7 World Health Organization. Listings of WHO's response to COVID-19: timeline. [Internet]. Geneva: WHO; 2020 [cited 2020 Aug 1]. Available from: https://www.who.int/ news-room/detail/29-06-2020-covidtimeline.

8 European Centre for Disease Prevention and Control. Daily update of new reported cases of COVID-19 by country worldwide [Internet]. Stockholm: ECDC; 2020 [cited 2020 Sep 11]. Available from: https://www.ecdc.europa.eu/en/publications-data/download-todays-data-geographic-distribution-covid19-cases-worldwide.

9 Andersen KG, Rambaut A, Lipkin WI, Holmes EC, Garry RF. The proximal origin of SARS-CoV-2. Nat Med. 2020 Apr;26(4):4502.

10 Seyran M, Pizzol D, Adadi P, El-Aziz TM, Hassan SS, Soares A, et al. Questions concerning the proximal origin of SARS-CoV-2. J Med Virol. 2021 Mar;93(3):1204-6.

11 Xiao J, Fang M, Chen Q, He B. SARS, MERS and COVID-19 among healthcare workers: A narrative review. J Infect Public Health. 2020 Jun;13(6):843-8.

12 Sousa-Uva AF. A saúde ocupacional e a pandemia da COVID-19: situações de risco específico [Internet]. Lisboa: Departamento de Saúde Ocupacional e Ambiental. ENSP. Universidade Nova de Lisboa; 2020 [cited 2020 Jun 30]. Available from: https://barometro-covid-19. ensp.unl.pt/wp-content/uploads/2020/04/ saude-ocupacional-03.04.2020.pdf.
13 Lidström AK, Sund F, Albinsson B, Lindbäck J, Westman G. Work at inpatient care units is associated with an increased risk of SARSCoV-2 infection; a cross-sectional study of 8679 healthcare workers in Sweden. Ups J Med Sci. 2020 Nov;125(4):305-10.

14 Iversen $\mathrm{K}$, Bundgaard $\mathrm{H}$, Hasselbalch RB, Kristensen JH, Nielsen PB, Pries-Heje M, et al. Risk of COVID-19 in health-care workers in Denmark: an observational cohort study. Lancet Infect Dis. 2020 Dec;20(12):1401-8.

15 Verschuuren M, van Oers H. Chapter 1: introduction. In: Verschuuren $M$, van Oers $H$, editors. Population health monitoring: climbing the information pyramid. Bilthoven: Springer; 2019.

16 World Health Organization. European Health Information Initiative. Copenhagen: WHO Regional Office for Europe; 2016 [cited 2020 Jun 30]. Available from: http://www. euro.who.int/_data/assets/pdf file/0004/287275/EHII_Booklet_EN_rev1. pdf?ua $=1$.

17 Oxman AD, Lavis JN, Lewin S, Fretheim A. SUPPORT Tools for evidence-informed health Policymaking (STP) 1: what is evidence-informed policymaking? Health Res Policy Syst. 2009 Dec;7(Suppl 1):S1.

18 World Health Organisation. Rational use of personal protective equipment for coronavirus disease 2019 (COVID-19): interim guidance 27 February 2020 [Internet]. Geneva: WHO; 2020. [cited 2020 Mar 1]. Available from: https://apps. who.int/iris/bitstream/handle/10665/331215/ WHO-2019-nCov-IPCPPE_use-2020.1-eng. pdf?sequence $=1$ \&isAllowed $=y$.

19 European Centre for Disease Prevention and Control. Contact tracing: public health management of persons, including healthcare workers, having had contact with COVID-19 cases in the European Union: second update, 8 April 2020: technical report [Internet]. Stockholm: ECDC; 2020. [cited 2020 Apr 10]. Available from: https://www.ecdc.europa.eu/ sites/default/files/documents/Contact-tracing-Public-health-management-persons-including-healthcare-workers-having-hadcontact-with-COVID-19-cases-in-the-European-Union-second-update_0.pdf.

20 European Centre for Disease Prevention and Control. Infection prevention and control for the care of patients with $2019-\mathrm{nCoV}$ in healthcare settings 2020: second update, 31 March 2020 [Internet]. Stockholm: ECDC; 2020. [cited 2020 Apr 4]. Available from: https://www.ecdc.europa.eu/sites/default/ files/documents/Infection-prevention-control-for-the-care-of-patients-with2019-nCoV-healthcare-settings_update31-March-2020.pdf.
21 Portugal. Ministério da Saúde. DGS. Novo Coronavírus COVID-19: relatório de situação: situação epidemiológica em Portugal, 30/06/2020. [Internet]. Lisboa: Direção-Geral da Saúde; 2020 [cited 2020 Dec 20]. Available from: https://covid19.min-saude.pt/wp-content/uploads/2020/07/120_DGS_boletim_20200630_02.pdf.

22 PORDATA. População residente, média anual: total e por grupo etário [Internet]. Lisboa: Fundação Francisco Manuel dos Santos;2020 [cited 2020 Dec 20]. Available from: https:// www.pordata.pt/Portugal/População+reside nte++média+anual+total+e+por+grupo+etá rio- 10 .

23 Lai X, Wang M, Qin C, Tan L, Ran L, Chen D, et al. Coronavirus Disease 2019 (COVID-2019) Infection among health care workers and implications for prevention measures in a tertiary hospital in Wuhan, China. JAMA Netw Open. 2020;3(5):e209666.

24 Lombardi A, Consonni D, Carugno M, Bozzi G, Mangioni D, Muscatello A, et al. Characteristics of 1573 healthcare workers who underwent nasopharyngeal swab testing for SARS-CoV-2 in Milan, Lombardy, Italy. Clin Microbiol Infect. 2020; 26(10):1413.e9-1413. e13.

25 Porru S, Carta A, Monaco MG, Verlato G, Battaggia A, Parpaiola M, et al. Health surveillance and response to SARS-CoV-2 mass testing in health workers of a large Italian hospital in Verona, Veneto. Int J Environ Res Public Health. 2020 Jul;17(14):5104.

26 Folgueira MD, Munoz-Ruiperez C, AlonsoLopez MA, Delgado R. SARS-CoV-2 infection in health care workers in a large public hospital in Madrid, Spain, during March 2020. medRxiv [Internet]. 2020 Jan 1 [cited 2020 Aug 31]; 2020.04.07.20055723. Available from: http://medrxiv.org/content/early/2020/04/27/2020.04.07.20055723.abstract.

27 Hunter E, Price DA, Murphy E, van der Loeff IS, Baker KF, Lendrem D, et al. First experience of COVID-19 screening of health-care workers in England. Lancet. 2020 May;395(10234):e77-8.

28 Keeley AJ, Evans C, Colton H, Ankcorn M, Cope A, State A, et al. Roll-out of SARS$\mathrm{CoV}-2$ testing for healthcare workers at a large NHS Foundation Trust in the United Kingdom, March 2020. Euro Surveill. 2020 Apr;25(14):2000433.

29 Kluytmans-van den Bergh MF, Buiting AG, Pas SD, Bentvelsen RG, van den Bijllaardt W, van Oudheusden AJ, et al. Prevalence and clinical presentation of health care workers with symptoms of coronavirus disease 2019 in 2 Dutch hospitals during an early phase of the pandemic. JAMA Netw Open. 2020 May;3(5):e209673. 